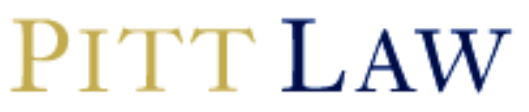

UNIVERSITY OF PITTSBURGH

Legal Studies Research Paper Series

Working Paper No. 2010-35

October 2010

\title{
Ornamental Repugnancy: \\ Identitarian Islam and the Iraqi Constitution
}

\author{
Haider Ala Hamoudi
}

University of Pittsburgh School of Law

3900 Forbes Avenue

Pittsburgh, Pennsylvania 15260-6900

www.law.pitt.edu

412.648.1490

E-mail: hamoudi@pitt.edu

This paper can be downloaded without charge from the

Social Science Research Network Electronic Paper Collection:

http:/ / ssrn.com/abstract $=1698447$ 


\title{
Article \\ Ornamental Repugnancy: Identitarian ISLAM AND THE IraQi CONSTITUTION
}

\author{
Haider Ala Hamoudi*
}

\section{Introduction-Semantic ObSessions}

Let me begin by positing a fact that as of the time of publication remains true, the explanation for which will be the subject of this essay. Nearly six years after the enactment of Iraq's final constitution, the Federal Supreme Court of Iraq has rendered only a single ruling ${ }^{1}$ respecting the conformity of any law to the "settled rulings of Islam" despite the Court being empowered to engage in precisely this type of review under Article 2 of the Iraqi Constitution. ${ }^{2}$

I shall turn to the single example of Article 2 review in a moment, for it is quite interesting and worthy of some consideration. For now, however, it suffices to say that if one's sole exposure to Iraq's constitution was through the literature produced by our legal scholars, the broad lack of concern with Article 2 would be not only startling, but, in fact, rather shocking. Article 2's so-called "repugnancy" provision has garnered a great deal of attention over the past several years. Ran Hirschl, for example, describes Iraq as part of a global phenomenon he calls "constitutional theocracy." 3 In an interesting article concerning the legitimacy of the invocation of a higher set of religious principles within a national constitutional framework, Larry

* Haider Ala Hamoudi is an Assistant Professor of Law at the University of Pittsburgh School of Law. He has recently returned from a year-long contract in Baghdad advising Iraq's legislature on, among other things, constitutional amendments and commercial and financial legislation. He is currently writing a book on the drafting and subsequent evolution of the Iraq Constitution. $738 /$.

1. Federal Supreme Court, Decision No. 60 of 2010, available at http://www.iraqja.iq/view.

2. Article 2, Doustour Joumhouriat al-Iraq [The Constitution of the Republic of Iraq] of 2005.

3. Ran Hirschl, The Rise of Constitutional Theocracy, 49 HaRv. InT'L. L.J. OnLine 72, 79 n.13, 82 (2008), www.harvardilj.org/attach.php?id=157. In fact, Hirschl's position is not far from my own, viewing as he does the constitutional system as a means to constrain more radical theocratic impulses. My own view is that inasmuch as Iraq is concerned, the supposedly radical theocrats themselves are not appreciably more interested in a truly robust role for shari'a than secularists. 
Catá Backer likewise categorizes Iraq as part of the rising trend of (to use his term) "theocratic constitutionalism." ${ }^{4}$ Noah Feldman goes further, finding in repugnancy, in Iraq as elsewhere, evidence of the "Rise of the Islamic State" after its dramatic collapse over a century ago. ${ }^{5}$ Yet one would expect that if Article 2 were so fundamental to the Iraqi legal framework as to constitute the "Rise of the Islamic State" or the advent of "theocratic constitutionalism," then surely the Iraqis themselves would have paid more than passing attention to it by now.

What might account for the near total indifference to Article 2? We may begin by leaving aside the more common and casual explanations that might be offered. The startling lack of attention does not lie in any general lack of activity on the part of the Federal Supreme Court, which has issued dozens of opinions each year on various constitutional provisions. ${ }^{6}$ Nor could it be related to the possible unwillingness of a supposedly weak judiciary to address sensitive matters, as the Federal Supreme Court has not hesitated to issue opinions on quite controversial (and constitutional) matters of considerable political import, including those pertaining to, for example, which political faction may have the first opportunity to form the new government after an election. ${ }^{7}$ Surely by now somebody should have invoked Article 2 to confront cornerstone provisions of existing Iraqi law; for example, the permissibility of money interest on a loan as set forth in the Iraqi Civil Code,${ }^{8}$ or the sections of the Personal Status Law that restrict, but do not prohibit, polygamy. ${ }^{9}$

The wide discrepancy between Western expectations and Iraqi reality is rooted in the manner in which commentators tend to study constitutions drafted under conditions similar to those of Iraq (or, put more precisely, after a dramatic political realignment). There is a depressing pattern in the publication of most work of this sort that seems rather difficult to dislodge. A constitution is enacted and there is a flurry of attention given to it immediately following its enactment, often by scholars whose knowledge of the domestic legal context in which the constitution is being enacted is limited, to say the least. Given this, the only truly reliable reference point for such scholars is the text of the constitution itself, often in translation, and whatever regional or global analogies the scholar may choose to draw. At some point not long after enactment, nearly all attention to the subject rapidly subsides as the new constitution no longer appears as new and there-

4. Larry Catá Backer, Theocratic Constitutionalism: An Introduction to a New Global Legal Ordering, 16 Ind. J. Global Legal Stud. 85, 150, 168 (2009).

5. Noah Feldman, The Fall and Rise of the Islamic State 11-14 (2008).

6. See The Judicial Authority, available at http://www.iraqja.iq/decision/ (last visited Jan. 29, 2011).

7. Federal Supreme Court, Decision No. 25 of 2010, available at http://www.iraqja.org/opn/ 25fed2010.htm.

8. Civil Code No. 40 of 1951, Article 692.

9. Personal Status Law No. 188 of 1959, Article 3(4). 
fore worthy of consideration. As a result, even years later, the only available scholarship focuses on the document at the moment of enactment. Such scholarship is, for the reasons set forth above, exceedingly textual, devoid of any mention of actual court practice in the state in which the constitution is being actively applied by the local judiciary, and therefore hardly an accurate barometer of relevant constitutional practice in the emerging constitutional state. ${ }^{10}$ Nowhere is this truer than in analyses of the Iraqi Constitution in general and of its articles respecting the role of Islam in the state in particular, where Iraqi praxis has been entirely disregarded in favor of linguistic rumination.

To be clear, there is nothing inherently wrong in the abstract with the scholarly approach I have outlined above, in the Iraqi context or outside it. For commentators such as Hirschl and Backer, for example, Iraq is only a passing and rather marginal example of what they view as a much broader phenomenon, and in that sense, their lack of attention to Iraqi praxis is understandable even if it does create a misimpression respecting the legal importance that may be attributed to Article 2. Even work that focuses more centrally on the constitutional phrasing in Iraq has its place. Thus, Professor Stilt's development of a range of possibilities concerning what the precursor to Article 2 of the Iraqi Constitution might mean, drawing upon other regional examples with which she is familiar to guide her, is insightful. ${ }^{11}$ The same might be said of comparable work from Intisar Rabb whose approach to Article 2, and in particular her rather fascinating comparison to Morocco, is noteworthy. ${ }^{12}$

10. Naturally, there are exceptions to such patterns. South Africa, for example, has continued to receive ample attention in United States legal scholarship long after the enactment of its constitution, thereby enabling access to the fascinating process of constitutional practice in that emerging democratic state. Perhaps this is because of its common law tradition, its use of English in matters of law, and the outstanding caliber of its own professoriate. For an excellent and brief example of such work in the context of the practical implementation of provisions concerning women's rights by the South African Constitutional Court, see Penelope Andrews, Evaluating the Progress of Women's Rights on the Fifth Anniversary of the South African Constitution, 26 VT. L. Rev. 829 (2002). See also Penelope Andrews, Perspectives on Brown: The South African Experience, 49 N.Y.L. SCH. L. Rev. 1155 (2005) (discussing the equality provisions of the South African constitution both as written and as developed by the Constitutional Court). South Africa is not the only example. In the matter of Islam and the state, there is also the substantial and laudable work of Clark Lombardi on the implementation of Article 2 of the Egyptian Constitution by the Supreme Constitutional Court of Egypt. See Clark B. Lombardi, State Law as Islamic Law in Modern Egypt: The Incorporation of the Shari'a into Egyptian Constitutional Law (2006). Nevertheless, these are exceptions that prove the rule. Even the most cursory Westlaw search will reveal that for the bulk of states with new constitutions following drastic regime changes, from Kosovo to Nepal, the scholarly attention for the most part is brief, focused on the period immediately following enactment, and written by authors whose knowledge of the state in question is, often by their own admission, limited.

11. See Kristen A. Stilt, Islamic Law and the Making and Remaking of the Iraqi Legal System, 36 Geo.Wash. Int'l L. Rev. 695 (2004).

12. Intisar A. Rabb, "We the Jurists": Islamic Constitutionalism in Iraq, 10 U. PA. J. Const. L. 527, 572-79 (2008). I say this with somewhat more misgiving given Rabb's rather perplexing insistence, on the basis of her own bare textual analysis, to declare particular readings of the text 
The point, therefore, is not so much to criticize such work as to qualify its importance. Specifically, while linguistic considerations and analyses based exclusively on text have their purposes, their value is largely limited to the period immediately following enactment. If I might draw upon an American analogy by way of illustration, hypothetically and anachronistically conceived, an informed, insightful, and scintillating law review article written upon the enactment of the U.S. Constitution might well discuss whether the Constitution would permit Congress to create a National Bank. Such an analysis might draw upon regional and global examples of relevance, point to broader global phenomena taking place at the time, and be worthy of consideration from academics and policy makers alike. It would be a rather depressing set of affairs, however, if scholarship like this were all that was said about the matter decades later, long after McCulloch $v$. Maryland, ${ }^{13}$ let alone the massive realignment of power following both the Civil War and the New Deal. A near-exclusive focus on text after much constitutional praxis is likely to lead to distorting results.

While clearly much less time has elapsed since the creation of the Iraqi Constitution as compared to the American, I fear that the near-exclusive linguistic focus has caused the broader legal community to miss an important post-ratification trend that has developed concerning Article 2. Specifically, the clause is swiftly devolving from a matter that was of some importance during constitutional negotiations into one that is more symbolic than real-an assertion of identity, primarily of the Islamic variety (though when combined with Article 92, to some extent of the Shi' $i$ Islamic variety) - rather than a phrase of legal substance. Iraqis appear to have reached a careful, unspoken consensus that, irrespective of the extent to which Islam or Islamic law is to be relevant in Iraq, the judiciary is not the institution best equipped to address questions of Islamicity of law, and thus Article 2, and indeed the very notion of repugnancy, is best rendered marginal in terms of its legal effect.

This is not to say, however, that the judiciary is entirely irrelevant as concerns Article 2, as the single example in which the Court agreed to address the question of repugnancy demonstrates. The Court does seem willing to tread carefully so as to justify and legitimize the fact that Iraq has replaced significant parts of Muslim private law (beyond the law of the family) with modern civil codes largely transplanted from Europe. However, as concerns areas of core religious concern for modern Muslims, the

(for example, the reference to "Islam" in Article 2 as being necessarily equivalent to "Islamic law") to be inevitable or unavoidable. $I d$. at 536-37. A less textual approach that gave primary voice in Iraqi constitutional interpretation to Iraqi decision makers would have revealed the existence of a vigorous debate even at the time of drafting and during the period immediately preceding it surrounding precisely what the reference to "Islam," as opposed to "Islamic law," was supposed to mean. This is meant only to qualify Rabb's otherwise insightful commentary.

13. 17 U.S. 316 (1819). 
Court does not appear interested in engaging in the debate, leaving the matter of the Islamicity of law therefore largely beyond its purview.

In order to understand how this came to be, some familiarity with Iraqi political influences and institutions is necessary. I therefore begin Part II of this essay with an examination of the relevant influences and institutions operating within Iraq, with particular emphasis on the special importance ascribed to the Najaf-based Shi'i clerical institution, the marja'iyya, whose role in the unfolding of Iraq's constitutional system (both as envisioned by the drafters and as developed through praxis) can scarcely be gainsaid. The balance of Part II of the essay describes the debates that arose during constitutional drafting as a result of the competing interests of these various institutions and influences, and the consensus that was reached in terms of the textual arrangement. Part III demonstrates that, in the half decade since enactment, emerging praxis has clearly tended to favor a reading of the text of Article 2 that renders it almost entirely about identity and not about juristic or judicial control over legislation to ensure Islamicity. The sole exception to this broad trend is also described in Part III. Part IV helps to explain why and how this consensus came about.

\section{DRAFTING}

By far the most important point respecting Islam and the state in Iraq, and one I have made repeatedly elsewhere, is that to the dominant Shi'a, the sole institution that may credibly interpret shari'a (defined for our purposes as the vast body of Muslim rules and norms derived from sacred text) is the marja'iyya. ${ }^{14}$ This is in contradistinction to a nation such as Sunni Egypt where the relevant Sunni clerical institution, the Azhar, has suffered a catastrophic loss of legitimacy, thereby enabling a court to determine shari'a without reference to the Azhar's contemporary scholars. ${ }^{15}$ The distinction is important and bears emphasis because it has tended to escape the notice of some contemporary scholars with regrettable results. ${ }^{16}$ Admittedly, in terms of legal and judicial structures, Iraq and Egypt are remarkably similar. In both countries, the judiciary is trained in secular legal traditions and in the positive enacted law of the state and unfamiliar with the learning methodologies and interpretive traditions of clerical institutions. ${ }^{17}$ In Iraq, however, a

14. See, e.g., Haider Ala Hamoudi, Orientalism and The Fall and Rise of the Islamic State, 2 Middle E. L. \& Governance J. 81, 89 (2010) (reviewing Feldman, supra note 5); Haider Ala Hamoudi, Money Laundering Amidst Mortars: Legislative Process and State Authority in PostInvasion Iraq, 16 Transnat'L L. \& Contemp. Probs. 523, 537, 540-41 (2007) [hereinafter Hamoudi, Money Laundering].

15. LOMBARDI, supra note 10, at 67-69.

16. See Hamoudi, Money Laundering, supra note 14, at 539-41 (describing common scholarly misimpressions created by comparing Shi'i-dominated Iraq with Sunni-dominated Egypt concerning the interpretation of Article 2).

17. Haider Ala Hamoudi, The Death of Islamic Law, 38 GA. J. InT'L \& Comp. L. 293, 311 (2010). 
vibrant, deeply respected, and deeply popular religious hierarchy remains in place in Najaf, and the idea that secular judges would be permitted to develop novel approaches to shari'a, or any aspect of Islam for that matter, in derogation of Najaf would be deeply offensive to core Shi'i sensibilities. ${ }^{18}$

To secular Sunnis and Shi' is alike, who do not wish for shari'a to play a large role in state affairs, this hardly poses a significant problem. The two are merely different sects of Islam, much as Roman Catholicism and Protestantism may be thought of as two sects of Christianity. As with Christianity, to the extent that some significant portion of Shi' is and Sunnis are either not very devout or at least are dismissive of any role for religion in matters of state and law, the religious differences between the two present no substantial difficulty. The secular Shi'a may turn to the marja'iyya on whatever matters of religious importance they deem necessary (the days of the religious holidays, for example) while the secular Sunnis may consult whatever authorities they wish, and none of this will have any impact on state law, which is organized and developed entirely differently.

The problem arises for the substantial proportion of Iraqis to whom I refer as "Islamists," by which I mean Iraqis who seek a greater role for shari' $a$ in the law of the state. For Islamist Shi'a, such Islamization necessarily requires juristic involvement at some level. In particular, the drafting of a repugnancy clause would have to involve juristic representation on whatever body makes final decisions respecting the constitutionality of legislation. The two propositions, one respecting the conformity of law to some conception of Islam or Islamic law, and the other respecting juristic representation on the constitutional body, were never separate for the Shi'a throughout constitutional negotiations.

To this end, early in the negotiations the Shi'i Islamists, at least in their most aggressive formulation, proposed that Article 2 declare that law could not violate the "rulings of the shari'a."19 In addition, a Shi'i Islamist proposal arose concerning what would become Article 92. It involved the creation of a "Constitutional Council" entirely separate from the judiciary. ${ }^{20}$ The Constitutional Council would be composed of eleven members, a bare

18. Hamoudi, Money Laundering, supra note 14, at 537.

19. This formulation respecting Article 2 is one that, according to my notes, was presented in the middle of June, shortly after the drafting committee had been formed, by Ahmed Al-Safi-a cleric, Grand Ayatollah Sistani's son-in-law, and the figure generally regarded by all involved in the negotiations as Sistani's spokesperson. I was given access to it by Sh. Humam Hamoudi, head of the legislature's Constitutional Committee (and, in full disclosure, my paternal uncle) in connection with an upcoming book I am writing on the Iraq constitution.

20. Shi'i Islamist Proposal, Article 92 [hereinafter Early Shi'i Islamist Proposal]. This Article 92 formulation appears unsigned in the constitutional records I have examined, but it is described as a proposal and, given its content, is surely from the Shi' a Islamist contingent. The idea of separating the Constitutional Council from the judiciary is not in and of itself novel. It is in fact the model used in France for the Conseil Constitutionnel. 1958 Const. Title VII (Fr.) (creating a Constitutional Council); id. at Title VIII (creating a judiciary that is independent of the Constitutional Council). 
majority of them jurists, with the balance being "legal experts." ${ }^{21}$ The function of this body would be to ensure constitutionality of legislation and, in an obvious redundancy given that Article 2 already constitutionalized shari'a, to "ensure the lack of a contradiction of the laws with the rulings of the shari'a."22

Most other Shi'i Islamist proposals contained in the records during this period of negotiation drop the majority jurist requirement for the Constitutional Council as well as the explicit reference to shari'a review (which is retained in Article 2), though such proposals retain a bare minority (at times four of nine, at other times five of eleven) of nonjudges-either experts in religion or law-on the putative Constitutional Council alongside judges. Given the prestige in the Shi'i public imagination accorded to jurists and the dramatic lack of familiarity on the part of judges with shari'a, the Islamists probably assumed, and probably correctly, that it was highly unlikely for all five judges on the Constitutional Council to vote unanimously against a united block of four jurists on a matter of shari'a. Nearly all relevant drafts also clearly grant the Council the ability to determine the constitutionality of legislation prior to enactment, as Deeks and Burton also report. $^{23}$

Yet all of this proved extraordinarily controversial. Just as the Shi' $i$ Islamists could not accept that the determination of shari'a would be left with secular jurists, every single other influence operating in Iraq opposed, at times rather vociferously, any notion of juristic involvement. The Kurds, a minority ethnic community comprising about twenty percent of Iraq's population, ${ }^{24}$ tended to favor more secular approaches and strict limits on religious influence over the state, ${ }^{25}$ and by the accounts of the members of the drafting committee with whom I have spoken, the U.S. Embassy strongly agreed. ${ }^{26}$ The Kurds were willing to accept some form of Islamic control over legislation in Article 2 (though in a weaker form than the Shi' $i$ Islamists proposed), ${ }^{27}$ but were adamant that the judiciary exercise control without the presence of jurists. ${ }^{28}$ The majority of secular Sunni nationalists agreed. ${ }^{29}$ For their part, Sunni Islamists had no objection to Article 2, even

21. Early Shi'i Islamist Proposal, supra note 20.

22. Id.

23. Ashley S. Deeks \& Matthew D. Burton, Iraq's Constitution: A Drafting History, 40 CoRNELL INT'L L.J. 1, 12-13 (2007).

24. Larry Diamond, Squandered Victory: The American Occupation and the BunGled EfFort to Bring Democracy to Iraq 21 (2005).

25. Deeks \& Burton, supra note 23, at 48.

26. Nearly every Shi'i Islamist member of the Constitutional Drafting Committee was of the view that the United States efforts concerning matters of Islam and the state were largely in favor of as much secularization as politically possible. Even Kurdish commentators, among them Fariad Rawanduzi and Fu'ad Ma'sum, tended to agree with this assessment.

27. Deeks \& Burton, supra note 23 , at 13.

28. Id. at 51 .

29. Id. 
if they proposed some significant modifications, ${ }^{30}$ but they were extremely concerned that juristic involvement on the Constitutional Council would be Shi'i dominated and result in a particularly strong Shi'i version of Islam prevailing. ${ }^{31}$ Even the United Nations weighed in heavily against juristic involvement. $^{32}$

In the end, a compromise could only be reached as to Article 2 where the constitution made clear that law could not be enacted that violated the "settled rulings of Islam" rather than, as the Shi'i Islamists wished, the "rulings of shari"a." ${ }^{33}$ This left much undetermined, as Stilt properly notes. ${ }^{34}$ Most importantly, it is not clear whether the replacement of shari'a with Islam changes much. Certainly the secular forces on the Constitutional Committee and L. Paul Bremer, the head of the United States civilian authority in Iraq when Iraq was under U.S. administration, ${ }^{35}$ felt that this change was significant, making Islam more a form of "inspiration" than a blueprint with which strict compliance was necessary. ${ }^{36}$ Moreover, the definition of "settled rulings" ${ }^{37}$ remains uncertain, as does the relationship between complying with Islam and complying with other provisions of the constitution-for example, those guaranteeing gender equality in Article 14. ${ }^{38}$ Much work would have to be done subsequent to ratification to clarify how all of this would work in practice.

Much less was agreed to concerning the final version of Article 92. The Shi'a Islamists and those opposing them each made one concession. The Shi'a Islamists agreed to make the Constitutional Council into a court, combining its functions with those of the Federal Supreme Court and retaining the "Federal Supreme Court" while removing the references to a Constitutional Council. At the same time, the Shi'a Islamists insisted that the Federal Supreme Court operate independently of the broader judicial administrative apparatus known as the Higher Judicial Council. ${ }^{39}$ In exchange, the Shi' a Islamists were able to extract a concession respecting Islamic ju-

30. In particular, Ayad Samara'i, according to the constitutional records I reviewed, wished to qualify the phrase "rulings of Islam" with "on which there is consensus," thereby ensuring that Sunni positions on Islam, and shari' $a$, might be heeded.

31. Deeks \& Burton, supra note 23 , at 14 . This was further confirmed in a conversation with Salim Al Jibouri, a high official within the Iraqi Islamic Party.

32. This was confirmed in a conversation with Abbas Bayati, an ethnic Turkoman who was part of the Shi'i Islamist Alliance, and Hamid Majid, a more secular presence on the drafting committee.

33. Article 2, Doustour Joumhouriat al-Iraq [The Constitution of the Republic of Iraq] of 2005.

34. Stilt, supra note 11 , at $741-42$.

35. DiAmOND, supra note 24 , at 13.

36. Stilt, supra note 11 , at 742 .

37. Deeks and Burton discuss this matter in some depth. Deeks \& Burton, supra note 23, at 14.

38. Article 14, Doustour Joumhouriat al-Iraq [The Constitution of the Republic of Iraq] of 2005 ("Iraqis are equal before the law without discrimination on account of their gender . . ..").

39. See id. at Article 92. 
rists. Article 92 clearly contemplates the presence of judges, legal experts, and experts in Islamic law ${ }^{40}$ on the Federal Supreme Court. However, the number of jurists (or judges for that matter), their means of appointment, and the manner in which the court goes about its work is left for subsequent legislation to be approved by a two-thirds vote of the legislature. ${ }^{41}$ The Court was thus a judicial body but potentially quite independent of the balance of the judiciary, staffed by judges, legal experts, and jurists in proportions to be determined subsequently.

\section{Toward a Working Consensus of IDENTITARIANism}

\section{A. Judicial Praxis}

Such was the situation upon ratification. It is important, however, to note one additional matter. In the interim period between enactment of the constitution and enactment of a law respecting a new court consistent with Article 92, the Iraqi political establishment, seemingly by unspoken consensus, has permitted the Federal Supreme Court that had been created by the interim constitution, the Transitional Administrative Law ("TAL"), ${ }^{42}$ to continue in force. ${ }^{43}$ Furthermore, a full six years after ratification of the constitution, the legislature remains unable to reach sufficient consensus to enact a law with the requisite two-thirds majority to create the Federal Supreme Court envisioned by the Constitution. As a result, the previous, and still existing, Federal Supreme Court remains responsible for interpreting constitutional provisions, and does so with some frequency.

This corrects a broad misconception that had previously arisen due to the mistaken position of one of the most respected authoritative voices on the Iraq Constitution, Andrew Arato, concerning what was to be done between ratification of the constitution and enactment of the law envisioned by Article 92. Arato assumed that during the interim period referenced above, there would be no court and therefore no form of constitutional review. ${ }^{44}$ The problem with this approach is that in the absence of any Federal Supreme Court, there would have been not only a complete lack of constitutional control over the legislature's enactment of law, but also no body to exercise core and essential functions assigned to the Court, such as ratification of election results and approval of the membership of the legis-

40. Id.

41. Id.

42. Diamond, supra note 24, at 394 (describing TAL in index as the "interim constitution").

43. No Iraqi government institution specifically conferred on the Federal Supreme Court created by the TAL the power to continue in force. It simply did, and, as a de facto matter, its rulings have been regarded as those of the highest body within Iraq's judiciary. This author knows of no serious challenge to its legitimacy as an interim institution.

44. Andrew Arato, Constitution Making Under Occupation: The Politics of Imposed ReVolution in Iraq 238 (2009). 
lative bodies. ${ }^{45}$ This would render the functioning of the state along constitutional lines all but impossible to imagine. This may well be why the approach has been to continue the existing Court indefinitely rather than dissolve it and leave nothing in its place pending Article 92 implementing legislation.

In any event, this continuation of the previous court has had two important consequences. First, it has resulted in de facto acceptance of the secularist position concerning juristic involvement. The Federal Supreme Court as it existed when the constitution was ratified was staffed entirely by judges and was very closely linked to the Higher Judicial Council and the broader judicial administrative apparatus. In fact, the head of the Federal Supreme Court, Medhat al-Mahmoud, also served, and continues to serve, as head of the Higher Judicial Council. ${ }^{46}$

Second, the continuation of the existing court added another powerful influence, that of Iraq's judiciary, onto the secularist side. While judges may vary widely in their religiosity, their professional training and culture diverges widely from the religious practices and culture of Najaf, ${ }^{47}$ and they were as unenthused as any over the prospect of jurists who knew not a thing about the methodologies of law sharing a bench with them. Based on my own conversations with the drafters of the Constitution, and by the accounts of others who have spoken with them, the judiciary has repeatedly opposed any suggestion to include jurists. ${ }^{48}$ When asked to recommend proposals respecting and implementing law for Article 92, which specifically contemplates juristic involvement, they have adopted the most minimalist reading imaginable. ${ }^{49}$ They have suggested that some very small number of jurists might sit solely as advisors rather than as full members of the court. ${ }^{50}$

While in many ways the status quo favored the secularist position, the Shi'a Islamists retained, and continue to retain, significant popular support, which grants them some measure of power as well. The two dominant Shi'a electoral lists-the Iraq National Alliance and Maliki's Rule of Law Coalition-control between them 159 out of 325 seats, not quite a majority but certainly much more than the largest Sunni coalition (91 seats) or the dominant Kurdish one (43 seats). ${ }^{51}$ Grand Ayatollah Sistani remains possibly the

45. Article 93(7), Doustour Joumhouriat al-Iraq [The Constitution of the Republic of Iraq] of 2005; id. at Article 52(2).

46. Discussion with Andrew Allen, Senior Adviser, Global Justice Project Iraq (Dec. 24, 2009).

47. See supra note 17 and accompanying text.

48. Jason Gluck, Senior Rule of Law Advisor, U.S. Inst. of Peace Rule of Law Ctr. of Innovation, Address at the University of Pennsylvania and National Constitutional Center Conference on Rule of Law Reform in Iraq and Afghanistan (Sept. 23, 2010).

49. Personal communication with Sh. Humam Hamoudi, chair of the Constitutional Committee.

50. Id.

51. Hannah Fairfield \& Archie Tse, The 2010 Iraqi Parliamentary Elections, N.Y. Times, Mar. 26, 2010, http://www.nytimes.com/interactive/2010/03/11/world/middleeast/20100311-iraq- 
most beloved popular figure in Iraq today; to doubt his authority is to court severe disapproval among many Shi' a. ${ }^{52}$ Or, as one prominent Shi'a Islamist member put the matter, "driving to work today I passed seven stores with the picture of Sayyid Sistani in them, and those were the ones I could see. Do you want to know how many pictures of [Supreme Court Chief Justice] Medhat al-Mahmoud I saw?"53

The Federal Supreme Court, therefore, does not particularly want jurists to sit on its bench, and the secularists in the legislature are capable of blocking legislation that would force their presence. At the same time, the Court, while enjoying a remarkable rise in legitimacy in its function as the authority responsible for the interpretation of $l a w,{ }^{54}$ does not enjoy anything like the type of popular support that Sistani commands, and certainly would have its credibility severely and strongly challenged if it dared to question Sistani. ${ }^{55}$ The result has been a marked reluctance on the part of the Court to address repugnancy very much so as not to stir the Shi'a into forcing a confrontation respecting juristic presence on the Court.

\section{B. Juristic Restraint}

On its own, this reluctance can hardly be the basis of an emerging consensus in that it seems as if it makes matters even worse for the Shi'a Islamist coalition. Under the current status quo, not only is Article 92 not implemented, but even Article 2 has been rendered meaningless in terms of its practical legal effect. In fact, Shi'i dissatisfaction did not arise because concomitant to the process of judicial avoidance of Article 2 was a corresponding lack of enthusiasm on the part of the Najaf jurists to involve themselves directly in matters of government.

In the fall of 2009, I managed a visit to all four of Najaf's Grand Ayatollahs, three of them (i.e. all but Sistani) with a large delegation. ${ }^{56} \mathrm{I}$

election.html?ref=middleeast. To be clear, the largest Sunni coalition in fact "won" the election in the sense that they received more votes than any other single electoral list, largely because the two dominant Shi' a factions were divided. Nevertheless, post-election political wrangling has led to Maliki's reinstatement as Prime Minister. John Leland \& Jack Healy, After Months, Iraqi Lawmakers Approve a Government, N.Y.TIMEs, Dec. 22, 2010, at A6.

52. DiAmOND, supra note 24 , at 127.

53. Personal communication with Shi'a Islamist member (Aug. 31, 2010). The question was rhetorical-in Iraq, as in the United States, the picture of the Chief Justice of the Supreme Court does not appear in very many public locations. This is, to be clear, not meant to be in any way a negative reflection on the admirable legal acumen of Judge Medhat, only an expression of the realities of public awareness of judicial figures anywhere, even significant ones.

54. Haider Ala Hamoudi, The Iraqi High Court's Understated Rise to Legitimacy, JuRIST (Apr. 23, 2010), http://jurist.law.pitt.edu/forumy/2010/04/iraqi-high-courts-understated-rise-to. php.

55. See supra note 52 and accompanying text.

56. The delegation included, in addition to myself, Gary Sick, former national security director to President Carter (and a current professor at Columbia University's School of International and Public Affairs), Richard Norton of Boston University, Dale Eickelman of Dartmouth, and Glen Howard of the Jamestown Foundation. 
was struck by how often and how forcefully all of them indicated that the marja'iyya was to play no direct role in government. Rather, the marja'iyya should only support, guide, and correct government from the outside, in the hopes that the government would heed its advice. ${ }^{57}$

There is considerable overstatement in this, at least as a statement of intent throughout the post-Saddam era. Indeed, there would have to be in order to make the debates over Article 2 and 92 make any sense at all. Yet it is also clear that Najaf's jurists, if they so desired, would have been able to assume more important state functions than they currently do. Sistani would not so much as meet with Bremer, preferring instead to exert his influence from the outside rather than to assume any formal role in governance. ${ }^{58}$ Even when the American occupation formally ended, neither Sistani nor any other major jurist sought any state positions.

In fact, even the juristic interventions into politics have been remarkably restrained. The Najaf jurists, led by Sistani, have never sought to use their influence to cause the state to prohibit the sale of alcohol, legislate women's dress, or impose the harsh criminal penalties derived from traditional readings of shari'a. Instead, their intervention pertains to such matters as the necessity of elections, ${ }^{59}$ anticorruption, ${ }^{60}$ and ensuring that educational materials do not foment sectarian division. ${ }^{61}$ It is understandable why the jurists might choose this course-for the most part, the jurists enjoy reasonable popularity even among Sunnis, Kurds, and secular or less religious Shi'a. This would almost certainly change if the jurists sought to use political influence to enforce religious law. They would become partisan figures and their popularity (and concomitant political influence) would almost surely begin to wane. It is one thing for Najaf to decry the disturbing tendencies of Iraq's political class to vote itself all sorts of perquisites of office; there are few who would object to Najaf's protestations of the political classes enriching themselves from the public coffers. By contrast, Iraq's significant drinking population would surely resist any attempt by Najaf to ban alcohol nationwide. The opposition among the moneyed classes, or among banking interests, to any attempt by Najaf to advocate in favor of the traditional shari'a prohibition on money interest on debt would be even more strident.

57. See Haider Ala Hamoudi, Navigating the Najaf Mantra with the Four Grand Ayatollahs, The Daily Star (Lebanon), Nov. 5, 2009, available at http://www.mallat.com/LawPageDS/ Hamoudi5Nov09.pdf.

58. DiAMOND, supra note 24 , at 83 .

59. ARAto, supra note 44, at 115.

60. In December of 2009 at a Friday sermon in the Kerbala Mosque, millions of Iraqis (including me) witnessed Ali Al-Safi, Sistani's son-in-law, take a strong, public, and widely discussed stand against the alleged free distribution of real estate to high government officials.

61. Steven Lee Myers, Iraqi Cleric Avoids Using His Power to Sway Voters, N.Y. Times, Mar. 3, 2010, at A4. 
Moreover, it is unclear why the Najaf jurists would necessarily want to demand nationwide shari'a compliance. In more religious, Shi'i dominated areas of the country, where tribes exert enormous influence and the word of Sistani is taken quite seriously, shari'a violations, such as the consumption of alcohol, nonmarital sex, and promiscuous dress, would never be conducted openly. These are close-knit communities where one's reputation and honor are of considerable importance. Violence is generally not necessary to ensure compliance, though at times both in Shi'i areas and outside of them, it is used with tragic results. ${ }^{62}$ A woman in Najaf would no more leave her home with her hair uncovered and a beer in her hand than a student of mine would appear in my classroom drunk wearing nothing more than a speedo swimsuit - a perfectly legal activity, even in the absence of violence. Shaming and communal enforcement tend to work in any society, but even more so in less individualistic ones than the United States. This is to say nothing of the ability of merchant communities to police themselves with a potential sanction for rule violations far more severe than the forced compensation the state might order; namely, exclusion from the community ${ }^{63}$ As a final matter, Najaf's political influence, and that of Sunni Islamists as well, is sufficiently strong so as to make it a matter of near certainty that the law will always pay some heed to core religious interests, to the extent they make themselves known.

In many ways, this system suits Najaf quite well-the jurists may control the areas under their influence without state interference through promulgating non-state rules. They may also enter the foray of politics to preserve key interests (elections, which the religious Shi' a naturally are able to win given their numerical superiority) or serve broader public interest goals (those respecting anticorruption), which have the salutary effect of enhancing their broader popularity. Moreover, all of this takes place in a political milieu in which it would be next to impossible to convince the majority of parliament to enact a law to which Najaf is implacably opposed. Thus, inasmuch as the state is concerned, Najaf's relative separation enables it to involve itself in politics at places and times of its own choosing without having to compromise its own interests. Najaf may pronounce shari'a without state interference and reasonably expect adherence among the Shi' a faithful and in Shi' a dominated areas, and it may enter the political fray where and when it chooses without being deemed to endorse all laws to which it fails to object.

By contrast, if Najaf jurists were actually on a Federal Supreme Court and were asked to decide whether or not a particular law (alcohol licensing

62. Damien Cave, Four Truck Bombs Kill 190 in Kurdish Area of Iraq, N.Y. Times, Aug. 15, 2007, at A1 (referring to the stoning of a Yazidi woman for dating a Sunni Arab man).

63. See, e.g., Haider Ala Hamoudi, Baghdad Booksellers, Basra Carpet Merchants, and the Law of God and Man: Legal Pluralism and the Contemporary Muslim Experience, 1 Berkeley J. Middle E. \& Islamic L. 83, 116-22 (2008). 
law, law respecting maximum interest rates, etc.) violated the "settled rulings" of Islam, to use the terminology of Article 2, the juristic ability to navigate political matters on their own terms would end. The positions taken by jurists on that court would either seem to legitimate whatever practice was being challenged on religious grounds, or the jurists on the court would be placed in the entirely unenviable position of having to prohibit a law that significant non-Shi'i (or Shi'i secular) portions of the population might find rather appealing, thereby incurring strong opposition. The ubiquitous pictures of Sistani, of which my parliamentary colleague was so proud, might become somewhat less prevalent. It is altogether easier for jurists to do as Grand Ayatollah Mohammad Saeed al-Hakeem did in his conversation with me, which was to carefully describe the rules respecting usury and then shake his head in genuine sadness when I told him of the ubiquity of money interest in modern global economies. If the Grand Ayatollah himself (or, more likely, an appointee) was placed on a court, this could not be as easily managed, as legal action would be required following the head shaking once a case was brought to the court. A judiciary composed of secular judges might be able to skillfully avoid the question of the Islamicity of money interest through any sort of combination of avoidance techniques (among them delays in hearing the case, expansions of political question doctrines, or deciding cases on procedural grounds without reaching constitutional merits), but a jurist on a court could hardly do the same without risking some credibility as to his determination to effect Islamization.

What therefore emerges from this complex web of institutional interests and rivalries is something of a consensus wherein the judicial authorities control law, the jurists control shari'a, and each endeavors to stay largely out of the way of the other. This is not, to be clear, Jefferson's "wall of separation."64 It is well known, for example, that Iraqi public schools have always mandated religious instruction and nobody of significance in Iraq is suggesting that this century-old system be changed. Nor is anyone suggesting that religious rules have no place in matters of law and government concerning family law in particular. Nevertheless, Iraq is developing into a legal and political system where, in contradistinction to the dictates of Article 2, shari'a exists not so much over law as alongside it.

\section{Qualifications-The Limits of Shari'a}

None of this explains the lone exception to the Court's unwillingness to address Article 2-Decision 60 of $2010 .{ }^{65}$ This is a matter that deserves

64. Letter from Thomas Jefferson, President, to Nehemiah Dodge, Ephraim Robbins \& Stephen S. Nelson, Danbury Baptist Association (Jan. 1, 1802).

65. Federal Supreme Court, Decision No. 60 of 2010, available at http://www.iraqja.iq/view. $738 /$. 
separate and special consideration. In that case, a party had sought to prove the existence of a construction contract between him and another party. ${ }^{66}$ When he was unable to produce a writing, and offered "personal evidence" instead, the case was dismissed in the lower court, pursuant to Article 77 of the Law of Evidence, which requires the existence of a contract over a set amount to be proved by means of a writing. ${ }^{67}$ The appellant's allegation was that the necessity of a writing to satisfy evidentiary requirements was a violation of Article 2 because it conflicts with shari'a. ${ }^{68}$

Before explaining the Court's basis for upholding the lower court decision (and thus Article 77 of the Evidence Law), it should be said that there is no requirement, or even recommendation, among shari'a authorities, Sunni or Shi' $i$, that a contract be placed in writing. If anything, the suggestion appears to be that oral contracts for sale are preferred, if not required. For example, Grand Ayatollah Sistani indicates that a contract for sale need not be concluded in Arabic, though he does indicate that the contract is concluded any time that one party "utters" a sale for a price, and the other party "utters" acceptance. ${ }^{69}$ For obvious reasons, there is a special dispensation for those unable to speak to grant acceptance through hand motions, and to those unable to move or to speak to rely on writings. ${ }^{70}$ More importantly, Sistani indicates there are two opinions respecting whether or not one capable of movement or speech may use a writing, and that the "more manifest" (a typical Shi'i juristic use of indirect terminology to express a preference) is that writings are acceptable. ${ }^{71}$ Grand Ayatollah Khu'i, who preceded Grand Ayatollah Sistani as the leading scholar in Najaf until his death in 1992, takes an even stricter view, suggesting that while there are two opinions, the "more manifest" merely "tolerates" writings if one is capable of speech. ${ }^{72}$ Finally, Sunni classical rules appear plainly to favor oral contracts over those conducted in writing, treating those in writing as having no evidentiary value, precisely the opposite conclusion of Article $77(2) .^{73}$

Thus, the Court could have determined that the pronouncements of the Grand Ayatollahs and the Sunni classical authorities favor oral contracts, and that therefore to require contracts to be in writing violates the "settled rulings" of Islam. It also had, however, ample resources at its disposal to suggest that there is no religious consensus on the matter. Classical Sunni opinion aside, it is self-evident that those organizing (Sunni-dominated) Is-

66. Id.

67. $I d$.

68. Id.

69. Ali Al-Husaini Al-Sistani, 2 Minhaj Al-Salihin If 51 (12th ed. 2008).

70. Id. at $\mathbb{I} 55$.

71. Id.

72. Abul Qasim Al-Khu’i, 2 Minhaj Al-Salihin 1051 (1992).

73. Jeanette A. Wakin, Introduction to The Function of Documents in Islamic Law 1, 6 , 10-11 (Jeanette A. Wakin ed., 1972). 
lamic finance at a major international bank such as HSBC would rely on written contracts. ${ }^{74}$ Moreover, as we have seen, the Grand Ayatollahs do at least "tolerate" written contracts. Taken together, while this does not mean Islam itself conclusively requires written contracts, the Court could credibly maintain that a state law requiring them is certainly not a violation of a "settled ruling."

The Court instead took a different and more provocative approach. In addition to maintaining that Article 77 did not contradict a "settled ruling" of Islam, it argued that requiring a written contract harmonized with Islam, citing two verses of the Qur'an in order to reach this conclusion. ${ }^{75}$ In other words, it did something that in the previous two sections I suggested it should be quite reluctant to do. It challenged the jurists, stating on the basis of Qur'anic text that in fact (and, implicitly, contrary to the juristic conclusions described in the previous few paragraphs) written contracts were at the very least Islamically recommended, if not required. This is certainly not the opinion of Sistani, who has described them as acceptable, based on a sounder opinion, but certainly not the preferred course.

Despite the obvious provocation, I maintain that this requires only a partial qualification of my earlier conclusions, one that I have described elsewhere at some length. ${ }^{76}$ The reality is that even though the jurists describe in detail the rules on shari'a as they concern matters of commerce, interest in them in the modern world is exceedingly slight with only two discrete exceptions, the historic rules translated in modern parlance to prohibitions on money interest and those concerning forms of speculation. ${ }^{77}$ Even in Iran, where jurists control the state, the state freely adopts transplanted French civil rules for contracts, and not the rules of the very jurists who run the state. ${ }^{78}$ Concerning such matters, the shari' $a$ is purely conceptual, theory without the slightest intent of practice, because the rules, as they exist, are simply incompatible with running a modern economy. ${ }^{79}$

Even a casual comparison of Sistani's rules and those of Iraqi law on the matter of the Court's decision is instructive as to why this is. Article 77 of the Law of Evidence imposes a writing requirement for transactions generally, while the rules of Sistani and Khu'i described above relate to a contract for sale. ${ }^{80}$ This is because the traditional Islamic rules have no general

74. See HSBC Amanah: Islamic FinANCE fOR Life, http://www.hsbcamanah.com (last visited Jan. 31, 2011). $738 /$.

75. Federal Supreme Court, Decision No. 60 of 2010, available at http://www.iraqja.iq/view.

76. Hamoudi, The Death of Islamic Law, supra note 17, at 323-25.

77. Haider Ala Hamoudi, The Muezzin's Call and the Dow Jones Bell: On the Necessity of Realism in the Study of Islamic Law, 56 Aм. J. Comp. L. 423, 445-47 (2008).

78. Hamoudi, The Death of Islamic Law, supra note 17, at 316.

79. Id. at 322 .

80. Compare Art. 77(2), Law of Evidence, No. 107 of 1979 (Iraq), with Sistani, supra note 69 , at II 55, KHU'I, supra note 72 , at II 51. 
theory of contract, but instead divide contract into nominate forms, among them sale, lease, partnership, and the like. ${ }^{81}$ If the Court actually wanted to take these rules seriously, it would have to examine the validity of Article 77 as against each shari' $a$ based nominate form of agreement and the rules of formation related to them, effectively exploding the general theory of contract upon which modern commercial systems are founded. To describe this as devastating from an economic perspective if carried out broadly is to understate the matter considerably.

Given the material realities, to ignore the bulk of Islamic rules as they pertain to commerce seems the only option, and the one taken by Islamic states and commercial actors alike, even devout ones. ${ }^{82}$ This gives the Court some purchase to use somewhat provocative reasoning to reach the conclusions it does respecting written contracts without fear of causing a juristic reaction. After all, if Iran's controlling juristic authorities do not care to adopt Islamic rules on contract, it is hard to believe that jurists in Iraq, given their restraint, will be very exercised about what the Court does to legitimate, on Islamic grounds or otherwise, thoroughly transplanted rules with roots now reaching back decades upon which its modern economy is based. The reaction would certainly not be the same were the Court to tread upon areas of religious doctrine that modern Muslims, within their own modern sensibilities and their framework understandings of Islam, would regard as core doctrine. This is probably why the Court chose to stake this ground on the matter of written contracts and not the permissibility of interest or rules concerning Islamic dress.

\section{Why Article 2?}

In some ways, the consensus reached, while salutary enough, is rather perplexing. Under this consensus, Iraqi jurists have been content with avoiding state enforcement of shari'a in the post-Saddam era. They are instead satisfied as to their ability to control their own constituencies and unconcerned with enforcement of shari'a on other domestic constituencies. Their primary interest lies in matters of policy and political interest that do not implicate the core of the traditional shari'a. Yet if all of this is true, then why would Islamists have bothered with Articles 2 and 92 in the first place? Surely all of it could have been achieved without reference to a state body empowered to invalidate law to the extent that it conflicts with "settled rulings" of shari'a. The simpler solution would have been to leave the court as it was (which ultimately occurred as a de facto matter anyway) and focus attention elsewhere.

Two explanations may be offered for the fight over Article 2. The first relates to an important shift in emphasis on the part of the Shi'a Islamists

81. Hamoudi, The Death of Islamic Law, supra note 17, at 308 n.70.

82. Id. at 322 . 
themselves by virtue of their continued political power. The second, more important explanation is somewhat subtler and relates to identitarian values rather than legal effects. I shall discuss each in turn.

\section{A. Comforts of Majoritarianism}

Turning first to the shift in emphasis, one cannot underestimate the continued hold of Saddam Hussein over the Shi'i imagination well into the drafting era. Accordingly, major figures within the Shi'i Islamist movement insist that the primary point of Article 2 was to limit state incursions on religious freedoms. ${ }^{83}$ Shi'i Islamists routinely insist that in the Saddam era, young Shi'i men would be afraid to attend the mosque because so many religious people were detained for no reason other than their religiosity. ${ }^{84}$ Prohibiting the state from violating the "settled rulings" of Islam ensures that the state cannot limit public prayer, religious dress, or force state workers to eat during daylight hours during the month of Ramadan as they allege Saddam to have done. While Islamists also indicate that they continue to think Article 2 is important for this reason and that Article 2 will not function properly without Article 92 legislation being enacted, there is no urgency to this because, at least for the moment, religious rights of this sort are not under threat. No law, they admit, could pass at this time and in this political environment that would violate Islam's "settled rulings."

At some level, this defense of Article 2 sounds preposterous. To say that religious rights of the sort the Islamists are discussing are not under threat is to understate the matter considerably. It is obvious to anyone who has worked with the Iraqi legislature even casually that there is not a single member who would, at least publicly, support the notion that the headscarf should be prohibited or that state workers should be forced to eat during Ramadan. To fear this seems almost paranoid, yet given the outrages of the previous regime and the extreme repression of the Shi'a during that period in which basic Shi'i rituals were prohibited ${ }^{85}$ the fear is, if nothing else, grounded in good faith. The impact of that severe repression on the Shi' a and their continued fear of a reversion to those times is very real. Yet at the same time, the relative strength of political movements based on Shi'i Islamism, which remain dominant in Iraq through 2010, helps Shi'i Islamists justify their seemingly indefinite deferral of Article 92 legislation, thereby making Article 2, to their mind, interpreted as it would under current conditions by a judiciary whose rulings on such matters they would never deem credible, effectively unenforceable.

83. Personal communications with Sh. Jalal uddin Al Sagir, Ali Allaq, and Sh. Humam Hamoudi, senior figures within the broader Shi'i Islamist movement.

84. Id.

85. See, e.g., Megan K. Stack, March of a Million Pilgrims Shows Shi'a Power, NewArk Star-Ledger, Apr. 22, 2003, at 6 (describing the first opportunity the Shi'a had in decades to practice basic religious rites). 
Still, a robust free exercise clause would have easily achieved the goal of protecting worship (and much less controversially). ${ }^{86} \mathrm{In}$ fact, there does seem to be more at work for the Shi'i Islamists than mere freedom of worship. There is no doubt in my mind, for example, that if anyone were politically naïve enough to propose a bill permitting same-sex marriage in Iraq, Najaf would object vociferously and lend its political weight to blocking such a measure, yet this would not implicate the religious rights of any of the Shi'i faithful. It was, after all, concern regarding how far Article 2 would be read to ensure Islamicity of legislation that led to Kurdish and secular objection to the robust forms of review originally proposed by the Islamist Shi'a. Nevertheless, it is fairly clear that whatever the Shi'a Islamists originally intended concerning the scope of Article 2 beyond the noncontroversial robust free exercise aspect they continually advance, at this point its legal interest to them has been largely muted. This is because of the combination of the judicial capture of the institution responsible for ensuring constitutionality of legislation, the relative comfort of the Shi'a that the power they yield in the legislature is sufficient to ensure whatever level Islamicity they desire, and the general juristic preference, for the reasons already described, to remain outside of state control.

\section{B. Identitarian Value}

There is more at work than this, however, given the continued rhetorical importance of Article 2 not only to the Shi'a, but to Sunni Islamists as well. There appears to be some form of identitarianism that animates much passion even (or perhaps especially) when the legal content of the provision is minimized or nearly eliminated. That is to say, it is less important that Article 2 as a legal matter be used to force legislation to comply with shari' $a$ than for it to be used as a forceful assertion of identity - to establish Iraq as a state that does not permit law to violate Islam's "settled rulings." Thus, for example, Iraqi politicians are unable to describe with any level of precision (or any consensus of any kind) what would violate a "settled ruling" and whether any existing legislation is subject to scrutiny. Yet the former speaker of the Iraqi legislature, the Sunni Mahmoud Al-Mashhadani, may declare in open session (and in full view of cameras broadcasting the matter to Iraqi television homes) that he would pound with his shoe any bill brought to him that contradicted shari'a. Mashhadani surely did not mean this as legal intent-he never sought to ban money interest, for examplebut the identitarian assertion that Iraqi law must conform to shari'a was important to make even if it was effectively devoid of legal content.

86. In fact, such a clause already exists. Article 43 of the Iraq Constitution guarantees freedom of worship and specifically mentions the previously banned Husseini rituals. Article 43, Doustour Joumhouriat al-Iraq [The Constitution of the Republic of Iraq] of 2005. 
To reiterate the point, no wall of separation exists between religion and state, and legislators certainly would not themselves consider enacting law that they believe in their own view (using whatever subjective and almost certainly arbitrary ${ }^{87}$ test they choose to apply) violates core Islamic teachings. Thus, it is not so much that Islam has no role in the state, as that the notion of repugnancy, by which I mean specifically the empowering of the judiciary (or any constitutional body) to void legislation that conflicts with some vision of Islam, is, from a legal standpoint with the exception described above (which, it might be said, legitimizes law rather than invalidates it), largely an empty one devoid of legal content and meant only as identity assertion. That is to say, as would be the case in the absence of a repugnancy clause, the legislature is entirely free to call upon Islamic values and to enact law referencing them to any extent that it wishes, subject only to the political constraint of retaining public favor.

Perhaps the greatest demonstration of the extent to which Article 2 has been rendered largely devoid of legal content lies in the story of the Kurdistan Constitution. Having developed a regional constitution in June of last year and aware of the serious controversy that would surely underlie some of its key provisions, ${ }^{88}$ Kurdish leaders made a series of late changes thereto, possibly in the hope (though ultimately a vain one) ${ }^{89}$ of muting Arab objection..$^{90}$ One of these changes was to conform Article 6 of the Kurdish Constitution to Article 2 of the Iraqi Constitution, making it impossible for regional law to violate shari' $a .^{91}$

This is rather remarkable considering that the Kurds, by and large more secular than their Arab brethren in Iraq, were, as I noted earlier, the strongest domestic force opposing the Article 2 formulations proposed by the Shi'i Islamists. One would not, therefore, expect the Kurds to empower their judiciary to invalidate legislation on the same basis. The fact that the Kurds were willing to do this, when in the Kurdish city of Suleymania alcohol is far easier to purchase than it is in the entire state of Pennsylvania, shows the extent to which, in Iraq, repugnancy has become more a matter of an assertion of a Muslim identity than it is a genuine intent to limit legisla-

87. See Hamoudi, The Death of Islamic Law, supra note 17, at 328-32 (criticizing repugnancy as being applied fundamentally inconsistently).

88. Michael J. Kelly, The Kurdish Regional Constitution Within the Framework of the Iraqi Federal Constitution: A Struggle for Sovereignty, Oil, Ethnic Identity, and the Prospects for a Reverse Supremacy Clause, 114 Penn St. L. Rev. 707, 709 (2010) (describing some of the more provocative aspects of the constitution).

89. While the Kurdish government approved the draft of the constitution, after high-level American intervention, it was not scheduled for referendum and thus is still not in force. $I d$.

90. Compare Draft Kurdistan Regional Const. (Oct. 13, 2008), available at http://www. gjpi.org/2009/06/24/draft-kurdish-constitution/, with Draft KuRdistan Regional Const.: UPDATED (June 24, 2009), available at http://www.gjpi.org/2009/06/24/draft-kurdish-constitution/.

91. Draft Kurdistan Regional Const., Article 6 (Oct. 13, 2008), available at http://www. gjpi.org/2009/06/24/draft-kurdish-constitution/; Draft Kurdistan Regional Const.: Updated, Article 6 (June 24, 2009), available at http://www.gjpi.org/2009/06/24/draft-kurdish-constitution/. 
tive discretion. The secular Kurds and the Shi'a Islamists do not agree on much concerning Islam and its role in the state beyond, that is, their willingness to proclaim that identity proudly and forthrightly.

\section{Conclusion-The Centrality of Praxis}

To students of American law, little of the increased marginalization of Article 2 should seem unfamiliar. There are various clauses in the United States Constitution that have been so narrowed by the Supreme Court as to be of virtually no practical import, perhaps most prominent among them the Privileges and Immunities Clause. ${ }^{92}$ Other clauses of once central importance, most importantly the Contract Clause, have been narrowed so substantially and are invoked so infrequently that most American law students often graduate without knowing their textual content, much less any precedent surrounding their interpretation. ${ }^{93}$

Nor should the notion of identitarian value to constitutional text seem entirely foreign to those familiar with the United States Constitution. In the 2010 midterm election cycle alone there have been dozens of references to "We the People" as some sort of full-throated expression of popular sovereignty, notwithstanding the fact that the clause itself, from a strictly legal point of view, has never been held in any notable precedent to mean anything at all.

The difference, in the end, lies less in the nature of the constitutions, or their means of evolution, than it does in the manner in which they are approached. In the United States, it seems rather uncontroversial to study our constitutional text as against the context in which it unfolds, both in the courts and beyond them. We understand some constitutional text to carry legal meaning, and other constitutional text to be more identitarian in nature. We are fully aware that somewhere between the text and its application lies a disparate community of institutions of influence with widely varying interests and abilities to control the interpretive process, and as a result we never declare constitutional meaning on the basis of text alone, without careful consideration of this broader context, and its influence on how the constitution will be understood.

By contrast, study of all too many foreign constitutions proceeds on grounds we might dismiss in the United States context as mechanical, simplistic, and naïve, focused as it is on text to the exclusion of praxis, and without due regard for the local community where the text will come to be

92. Jack M. Balkin, Abortion and Original Meaning, 24 Const. Comment 291, 313 (2007) (disapprovingly describing the clause as being "effectively read out of the Constitution . ...").

93. James W. Ely, Jr., Whatever Happened to the Contract Clause?, 4 Charleston L. Rev. 371 (2010) (describing the Contract Clause as having "undergone such a dramatic decline," and offering a personal anecdote concerning a top student who was unfamiliar with the clause entirely). 
applied. ${ }^{94}$ Nowhere is this sin more obvious than in considerations of shari' $a$ and law where the prevailing assumptions are characterized by what my learned and justifiably well-regarded colleague Russell Powell would describe as "essentialism," 95 or what I might refer to as the reification of shari'a. The assumption appears to be that shari'a is some absolute, unchanging, globally recognized whole, and that therefore once a decision is made to conform law to shari' $a$, assumptions may be drawn about what this means, and its consequences for the state, in the absence of praxis on the part of local decision-makers. It is not, to reiterate, a position that would be taken remotely seriously in the American academy if advanced in the American context.

There is some irony to this. Upon first reflection, it might appear as if American commentators are ill-equipped to discuss constitutions in the Islamic world in particular given the vastly different cultural context. While there may be some truth to this, very often the problem is in fact the reverse. We do not, by and large, lack the methodological tools to understand constitutional text and praxis in Muslim countries; in fact, we have those tools in abundance. The real problem, all too often, is no more than an unwillingness to use them.

94. See supra Part I.

95. Russell Powell, Assoc. Professor of Law, Univ. of Seattle Sch. of Law, Address at the University of St. Thomas Law Journal Spring 2010 Symposium: Islamic Law and Constitutional Liberty (Apr. 8, 2010). 